\title{
Healing Effects of Single-Dose Triptolide in Rats with Severe Acute Pancreatitis
}

\author{
Şiddetli Akut Pantreatitli Ratlarda Tek-Doz Triptolitin İyileşmeye Etkisi
}

\author{
Hüseyin ÖZDEN ${ }^{1}$ \\ (1) 0000-0002-2786-3805 \\ Asuman KİLITTÇ $\dot{I}^{2}$ \\ (D) 0000-0002-5489-2222 \\ Yaşar ŞAHIIN ${ }^{3}$ \\ (D) 0000-0001-5936-4210 \\ Gökhan KARACA ${ }^{4}$ \\ (D) 0000-0002-5107-5999 \\ Haldun UMUDUM ${ }^{5}$ \\ (D) 0000-0002-4550-1971 \\ Ahmet YILDIZ ${ }^{4}$ \\ (iD) 0000-0002-6889-4528 \\ Erkan DULKADİROĞLU6 \\ (i) 0000-0001-7665-7453
}

${ }^{1}$ Ahi Evran University Faculty of Medicine Department of General Surgery, Kırşehir, Turkey

${ }^{2}$ Ahi Evran University Faculty of Medicine Department of Pathology, Kırşehir, Turkey

${ }^{3}$ Kırıkkale University Faculty of Veterinary Medicine Department of Pharmacology and Toxicology, Kırıkkale, Turkey

${ }^{4}$ Kırıkkale University Faculty of Medicine Department of General Surgery, Kırıkkale, Turkey

${ }^{5}$ Ufuk University Faculty of Medicine Department of Pathology, Ankara, Turkey

${ }^{6}$ Kırşehir Training and Research Hospital Internal Medicine Clinic, Kırşehir, Turkey

\section{Corresponding Author Sorumlu Yazar \\ Hüseyin ÖZDEN \\ huseyinozden@ahievran.edu.tr}

Received / Geliş Tarihi : 29.04.2020 Accepted / Kabul Tarihi : 26.06.2020 Available Online /

Çevrimiçi Yayın Tarihi : 25.08.2020

\begin{abstract}
Aim: Severe acute pancreatitis (SAP) carries high morbidity and mortality risk. If the proinflammatory response phase of SAP cannot be controlled, it may result in multiorgan failure (MOF). Nuclear factor-kappa $B(N F-\kappa B)$ activation plays an important role in the development of MOF. In this study, it was aimed to investigate the healing effects of triptolide, an anti-inflammatory and immunosuppressive agent in rats with SAP.

Material and Methods: A total of 20 Wistar-Albino rats were divided into two groups as the SAP and triptolide treatment (TT) groups. SAP was induced by intraperitoneal injection of cerulean $(50 \mathrm{mg} / \mathrm{kg})$ in both groups. TT group was administered a single dose $(0.2 \mathrm{mg} / \mathrm{kg})$ triptolide 24 hour after the induction of SAP. Serum ALT, AST, GGT, Lipase, Glucose, ALP and amylase levels and pancreatic tissue samples were examined.

Results: Serum glucose and amylase levels were found to be significantly lower in the TT group ( $\mathrm{p}=0.011$ and $\mathrm{p}=0.035$, respectively). There was no significant difference between the groups in terms of other biochemical parameters. Pancreatic edema, acinar cell degeneration, fat necrosis, intrapancreatic\&perivascular inflammation, inflammation in the peripancreatic fat tissue were common histopathological findings in both groups. There was no significant difference between the groups in terms of histopathologic changes.

Conclusion: Cerulein-induced pancreatitis is a successful method for experimental SAP. The healing effects of single-dose triptolide treatment are not evident in the early phase of SAP. The therapeutic effects of triptolide on inflammatory and oxidative stress were not significantly approved by histopathological and biochemical parameters by the pancreatic tissue. Keywords: Severe acute pancreatitis; cerulean; triptolide.
\end{abstract}

ÖZ

Amaç: Şiddetli akut pankreatit (SAP) yüksek morbidite ve mortalite riski taşır. SAP'nin proenflamatuar yanıt fazı kontrol edilemezse, çoklu organ yetmezliği (ÇOY) ile sonuçlanabilir.

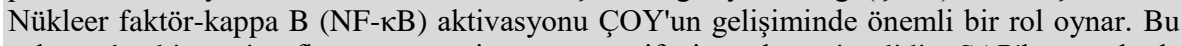
çalışmada, bir anti-enflamatuar ve immünsüpresif ajan olan triptolidin SAP'lı sıçanlarda iyileştirici etkilerinin araştırılması amaçlanmıştır.

Gereç ve Yöntemler: Toplam 20 Wistar-Albino sıçanı SAP ve triptolide tedavi (TT) grubu olmak üzere iki gruba ayrıldı. SAP her iki grupta da intraperitoneal cerulein $(50 \mathrm{mg} / \mathrm{kg})$ enjeksiyonu ile indüklendi. TT grubuna, SAP indüksiyonundan 24 saat sonra tek bir doz $(0.2$ $\mathrm{mg} / \mathrm{kg}$ ) triptolid uygulandı. Serum ALT, AST, GGT, Lipaz, Glikoz, ALP ve amilaz düzeyleri ve pankreatik doku örnekleri incelendi.

Bulgular: Serum glukoz ve amilaz düzeyleri TT grubunda anlamlı olarak daha düşük bulundu (sırasıyla $\mathrm{p}=0.011$ ve $\mathrm{p}=0.035$ ). Diğer biyokimyasal parametreler açısından gruplar arasında anlamlı bir fark yoktu. Pankreas ödemi, asiner hücre dejenerasyonu, yăg nekrozu, intrapankreatik\&perivasküler inflamasyon ve peripankreatik yağ dokusunda inflamasyon her iki grupta da sık görülen histopatolojik bulgulardı. Gruplar arasında histopatolojik değişiklikler açısından anlamlı bir fark yoktu.

Sonuç: Cerulein kaynaklı pankreatit, deneysel SAP için başarılı bir yöntemdir. Tek doz triptolid tedavisinin iyileştirici etkileri SAP'nin erken evresinde belirgin değildir. Pankreatik doku histopatolojik ve biyokimyasal parametreler açısından incelendiğinde, triptolidin enflamatuar ve oksidatif stres üzerindeki terapötik etkileri yeterli düzeyde değildi.

Anahtar kelimeler: Şiddetli akut pankreatit; cerulein; triptolid. 


\section{INTRODUCTION}

The clinical spectrum of acute pancreatitis ranges from mild and treatable with supportive measures to severe diseases with life-threatening complications. Severe acute pancreatitis (SAP) is the most serious type of pancreatitis and has a high morbidity and mortality risk. SAP occurs in two phases. Initially, proinflammatory response develops during the first 1-2 weeks and results in systemic inflammatory response syndrome (SIRS). After the first 1-2 weeks, the anti-inflammatory response occurs. In the presence of severe SIRS, proinflammatory mediators may lead to early multiple (respiratory, cardiovascular, renal and hepatic) organ failure $(1,2)$.

Activation of transcription factor nuclear factor-kappa B (NF-kB) in acinar cells during the early stage of pancreatitis triggers the expression of multiple proinflammatory genes. It has been postulated that there is a positive correlation between NF- $\mathrm{KB}$ levels and the severity of acute pancreatitis. Experimental studies have reported NF- $\mathrm{KB}$ activation to be an early and central event in the progression of inflammation in AP (3-5).

Triptolide is extracted from the roots of Chinese herb Tripterygium wilfordii and is known as an NF- $\mathrm{kB}$ inhibitor. Previous studies have shown that triptolide has a broad-spectrum therapeutic potential due to its immunosuppressive, anti-inflammatory and anti-tumor properties (6-8).

Our experimental study aimed to investigate the healing effects of single dose-triptolide treatment in the early phase of cerulein-induced severe acute pancreatitis in rats.

\section{MATERIAL AND METHODS}

This study was conducted with the permission of Kirıkkale University's Local Ethics Committee for Animal Experiments (08.01.2019 and decision no: 11). A total of twenty male Wistar albino rats weighing $280 \pm 20 \mathrm{~g}$ were randomly divided into two groups ( $\mathrm{n}=10$ each group) as the SAP and triptolide treatment (TT) groups. All rats were fasted for 12 hours before the experimental procedure, but were given free access to ad libitum and food, and also kept to standard animal care conditions $\left(22 \pm 2^{\circ} \mathrm{C}\right)$ with a 12:12-h light: dark cycle. Severe pancreatitis was induced by intraperitoneal injection of cerulein $(50 \mathrm{mg} / \mathrm{kg})$ to both groups. The TT group was administered a single dose $(0.2$ $\mathrm{mg} / \mathrm{kg}$ ) of intraperitoneal triptolide 24 hours after the development of severe pancreatitis. All surgical procedures were performed using $10 \mathrm{mg} / \mathrm{mL}$ xylazine (Rompun; Bayer) and $50 \mathrm{mg} / \mathrm{mL}$ ketamine (Ketalar; JHP), given intramuscularly into the leg of the rats at a dose of $0.25 \mathrm{~mL} / 100 \mathrm{~g}$ of rat mass prior to the application. All rats were sacrificed 48 hours after the development of severe pancreatitis. Rats were sacrificed by cardiac puncture. Biochemical and histopathological tissue samples were obtained from all rats by laparotomy. Blood samples were separated immediately by centrifugation at $4000 \mathrm{rpm}$ for 5 minutes and stored at $-20^{\circ} \mathrm{C}$ for biochemical analysis. About $4 \mathrm{ml}$ was drawn from the left ventricle, centrifuged and observed by an auto biochemistry analyzer for ALT, AST, GGT, Lipase, Glucose, ALP and amylase levels. Pancreatic tissues of all rats were sampled for histopathologic examination for the severity of acute pancreatitis.

\section{Histopathological Evaluation}

Pancreatic-tissue samples fixed in $10 \%$ formalin were embedded in paraffin, cut into $4 \mu \mathrm{m}$ sections, placed on slides and stained with hematoxylin and eosin (H\&E). Slides were examined under a light microscope by two pathologists who were blinded to the experimental procedure. A modified semi-quantitative scoring was performed for the microscopic evaluation of the pancreatitis and four categories (Grade 0: none, 1: low, 2: moderate, 3: severe) were defined. To grade the damage to the pancreas, edema, acinic cell degeneration, acinar necrosis, fat necrosis, hemorrhage, intrapancreatic and perivascular inflammation, inflammation in the peripancreatic fat tissue were included as the parameters of the scoring system.

\section{Statistical Analysis}

SPSS v.21.0 was used for the statistical analysis of the study. Assumption of normality was tested by ShapiroWilk tests. Explanatory statistics for variables were given as mean \pm standard deviation or median, interquartile range (IQR), minimum-maximum, and number and percentage. Group comparisons were made using the Independent samples t-test, Mann-Whitney U test, Fisher's Exact test and Fisher-Freeman-Halton test according to the type of variables and the state of the verification of assumptions. A p-value $<0.05$ was considered statistically significant.

\section{RESULTS}

The mean ALT, AST, GGT, lipase, and ALP levels of the groups were not significantly different. The mean serum glucose levels of the SAP group were significantly higher compared to the TT group $(\mathrm{p}=0.011)$. The mean serum amylase levels were also significantly higher in the SAP group compared to the TT group ( $\mathrm{p}=0.035)$. The statistical comparisons of the groups in terms of blood parameters including ALT, AST, GGT, lipase, glucose, ALP and amylase levels are presented in Table 1 in detail.

Table 1. Comparison of the groups in terms of pancreatic and liver enzyme levels

\begin{tabular}{lccc}
\hline & SAP group $(\mathbf{n = 1 0})$ & TT group $(\mathbf{n = 1 0})$ & p \\
\hline ALT & $53.5 \pm 7.84$ & $56.0 \pm 13.86$ & $0.626^{\mathrm{a}}$ \\
ALP & $265.3 \pm 81.55$ & $272.4 \pm 72.52$ & $0.839^{\mathrm{a}}$ \\
Glucose & $137.6 \pm 4.16$ & $128.7 \pm 8.99$ & $\mathbf{0 . 0 1 1}^{\mathrm{a}}$ \\
AST & $121.0(30.25)[117-151]$ & $151.0(48.25)[114-173]$ & $0.315^{\mathrm{b}}$ \\
GGT & $1.0(1.0)[1-2]$ & $1.0(1.0)[1-6]$ & $0.912^{\mathrm{b}}$ \\
Lipase & $3.0(1.0)[2-3]$ & $3.0(0.0)[2-4]$ & $0.190^{\mathrm{b}}$ \\
Amylase & $1813.0(490.5)[1493-2588]$ & $1682.0(367.5)[1017-1838]$ & $\mathbf{0 . 0 3 5}^{\mathrm{b}}$ \\
\hline
\end{tabular}

SAP: Severe Acute Pancreatitis, TT: Triptolide Treatment, ${ }^{a}:$ Independent samples $t$ test, ${ }^{b}:$ Mann-Whitney U test, Descriptive statistics were given as mean \pm standard deviation or median (interquartile range) [minimum-maximum] 
A statistically significant difference was found only in fat necrosis. However, there was no significant difference in other parameters. Histopathologically, there was no significant difference between the groups in terms of edema, acinar cell degeneration, or intrapancreatic\&perivascular inflammation findings. Also, the fat necrosis, hemorrhage, inflammation in the peripancreatic fat tissue outcomes of both treatment groups were superior, but this difference was not statistically significant. Table 2 presents in detail the comparisons of the groups in terms of histopathological changes. The difference between the histopathologic changes in the groups was not statistically significant.

\section{DISCUSSION}

Severe acute pancreatitis comprises about $20 \%$ of all acute pancreatitis cases and may lead to local and systemic complications. Organ failure is commonly seen in the early period of acute pancreatitis (9). About 35\%-50\% of hospital deaths seen within the first week after admission are due to single or multiple organ failure. The pathogenic mechanism, pathologic process and management of SAP have yet to be completely clarified. Thus, the incidence of serious complications of SAP and morbidity rates could not be substantially decreased $(8,10-12)$.

Previous studies showed that NF- $\mathrm{B}$ plays a critical role in the clinical course of pancreatitis. Experimental studies showed that the activation of NF- $\mathrm{B}$ occurs within pancreatic acinar cells in the early phase of acute pancreatitis. NF- $\kappa \mathrm{B}$ is widely accepted as a key modulator in the regulation of inflammation due to its ability to

Table 2. Comparisons of the groups in terms of histopathologic changes

\begin{tabular}{|c|c|c|c|}
\hline & $\begin{array}{c}\text { SAP group } \\
(\mathrm{n}=10)\end{array}$ & $\begin{array}{c}\text { TT group } \\
(\mathbf{n}=10)\end{array}$ & $\mathbf{p}$ \\
\hline \multicolumn{4}{|l|}{ Edema } \\
\hline 1 & $4(40.0)$ & $6(60.0)$ & \multirow{3}{*}{$0.370^{\mathrm{a}}$} \\
\hline 2 & $6(60.0)$ & $3(30.0)$ & \\
\hline 3 & $0(0.0)$ & $1(10.0)$ & \\
\hline \multicolumn{4}{|c|}{ Acinar Cell Degeneration } \\
\hline 0 & $6(60.0)$ & $3(30.0)$ & \multirow{3}{*}{$0.103^{\mathrm{a}}$} \\
\hline 1 & $2(20.0)$ & $7(70.0)$ & \\
\hline 3 & $2(20.0)$ & $0(0.0)$ & \\
\hline \multicolumn{4}{|c|}{ Fat Necrosis } \\
\hline 1 & $6(60.0)$ & $3(30.0)$ & \multirow{3}{*}{$0.045^{\mathrm{a}}$} \\
\hline 2 & $4(40.0)$ & $2(20.0)$ & \\
\hline 3 & $0(0.0)$ & $5(50.0)$ & \\
\hline \multicolumn{4}{|c|}{ Hemorrhage } \\
\hline 0 & $10(100)$ & $6(60.0)$ & \multirow{3}{*}{$0.087^{\mathrm{a}}$} \\
\hline 1 & $0(0.0)$ & $2(20.0)$ & \\
\hline 2 & $0(0.0)$ & $2(20.0)$ & \\
\hline \multicolumn{4}{|c|}{$\begin{array}{l}\text { Intrapancreatic and } \\
\text { perivascular inflammation }\end{array}$} \\
\hline 0 & $6(60.0)$ & $5(50.0)$ & \multirow[t]{2}{*}{$1.000^{\mathrm{b}}$} \\
\hline 1 & $4(40.0)$ & $5(50.0)$ & \\
\hline \multicolumn{4}{|c|}{ Asinar Necrosis } \\
\hline 0 & $10(100)$ & $10(100)$ & --- \\
\hline \multicolumn{4}{|c|}{$\begin{array}{l}\text { Inflammation in the } \\
\text { peripancreatic fat tissue }\end{array}$} \\
\hline 0 & $0(0.0)$ & $1(10.0)$ & \multirow{3}{*}{$0.370^{\mathrm{a}}$} \\
\hline 1 & $6(60.0)$ & $3(30.0)$ & \\
\hline 2 & $4(40.0)$ & $6(60.0)$ & \\
\hline
\end{tabular}

control the expression of inflammatory mediators. The relationship between the level of NF- $\kappa \mathrm{B}$ activation and the severity of acute pancreatitis has been well-defined. Thus, treatment strategies aimed to inactivate NF- $\kappa \mathrm{B}$ seem to be reasonable and promising (13-16).

Gukovsky et al. (14) showed that the NF- $\kappa B$ is activated in pancreatic acinar cells within $30 \mathrm{~min}$ after ceruleininduced pancreatitis. A cerulein-induced experimental acute pancreatitis model was performed in our study. This model is the most widely preferred experimental animal model of acute pancreatitis as it is highly reproducible and cost effective (17-19). Intravenous or intraperitoneal injection of overdose $(0.5 \mu \mathrm{g} / \mathrm{kg} / \mathrm{hr}$ in rats $)$ cerulein induces pancreatic enzyme activation within 30 minutes. Findings in cerulein-induced experimental acute pancreatitis are similar and comparable to those of acute pancreatitis in humans. Besides that hyperamylasemia, histopathological findings such as the infiltration of inflammatory cells within the pancreas, pancreatic edema, acinar cell degeneration and the presence of activated pancreatic enzyme in pancreatic tissue are similar in experimental pancreatitis models and humans with pancreatitis (17).

Histopathological changes in the pancreatic tissues of the animals in our study groups were consistent with the outcomes in the literature. A single-dose intraperitoneal cerulein injection resulted in edema, acinar cell degeneration and inflammatory cell infiltration in the pancreatic tissue of rats. In our study, there was no statistical difference between histopathological assessment results. However, the hemorrhage and fat necrosis outcomes of the treatment groups were better. We believe the reason that our results were not statistically significant may be because of the small number of experimental rats in the study groups.

Triptolide is reported as a strong anti-inflammatory and immunosuppressive agent in the literature. These properties of triptolide are explained by the inhibition of the production of cytokines such as TNF-alpha, IL-1, IL-6, IL-8 and phagocytosis of phagocytes. It has been shown that these effects of triptolide are closely related to $\mathrm{NF}-\kappa \mathrm{B}$ activity $(7,8,20)$. Gray et al. (21) reported that lung and liver damage occur due to the activation of NF- $\kappa \mathrm{B}$ in the presence of pancreatitis-induced SIRS. Zhao et al. (8) showed that the activation of NF- $\kappa \mathrm{B}$ occurs in Kupffer cells in the liver tissue of rats with SAP and leads to an increase in serum TNF-alpha, IL-6 and ALT levels. They also showed that triptolide treatment inhibits $\mathrm{NF}-\kappa \mathrm{B}$ activity and considerably decreases serum TNF-alpha, IL-6 and ALT levels.

Our main limitation in this study was the lack of sham group of animals. We also could not examine the cytokine (TNF-alpha, IL-1, IL-6) levels due to our limited budget.

\section{CONCLUSION}

While triptolide used in the treatment of acute pancreatitis suggests an improvement in the clinics of acute pancreatitis by lowering amylase levels, one of the most important indicators of acute pancreatitis, we do not think it is suitable for use in the treatment of acute pancreatitis due to its negative effect on liver function tests.

Our results showed that triptolide treatment significantly decreases serum glucose and amylase levels in rats with 
SAP. However, there was no significant difference between the groups in terms of serum ALT, AST, GGT, lipase and ALP levels. The present study shows that triptolide cannot be used to treat severe pancreatitis relying on its antioxidant and pancreatoprotective feature.

\section{REFERENCES}

1. Portelli M, Jones CD. Severe acute pancreatitis: pathogenesis, diagnosis and surgical management. Hepatobiliary Pancreat Dis Int. 2017;16(2):155-9.

2. Zerem E. Treatment of severe acute pancreatitis and its complications. World J Gastrenterol. 2014;20(38):13879-92.

3. Huang H, Liu Y, Daniluk J, Gaiser S, Chu J, Wang H, et al. Activation of nuclear factor- $\kappa \mathrm{B}$ in acinar cells increases the severity of pancreatitis in mice. Gastroenterology. 2013;144(1):202-10.

4. Jakkampudi A, Jangala R, Reddy BR, Mitnala S, Nageshwar Reddy D, Talukdar R. NF- $\kappa \mathrm{B}$ in acute pancreatitis: Mechanisms and therapeutic potential. Pancreatology. 2016;16(4):477-88.

5. Watanabe T, Kudo M, Strober W; Immunopathogenesis of pancreatitis. Mucosal Immunol. 2017;10(2):283-98.

6. He L, Peng X, Liu G, Tang C, Liu H, Liu F, et al. Antiinflammatory effects of triptolide on $\operatorname{IgA}$ nephropathy in rats. Immunopharmacol Immunotoxicol. 2015;37(5):421-7.

7. Song C, Wang Y, Cui L, Yan F, Shen S. Triptolide attenuates lipopolysaccharide-induced inflammatory responses in human endothelial cells: involvement of NF- $\mathrm{B}$ pathway. BMC Complement Altern Med. 2019;19(1):198.

8. Zhao YF, Zhai WL, Zhang SJ, Chen XP. Protection effect of triptolide to liver injury in rats with severe acute pancreatitis. Hepatobiliary Pancreat Dis Int. 2005;4(4):604-8.

9. Garg PK, Singh VP. Organ failure due to systemic injury in acute pancreatitis. Gastroenterology. 2019;156(7):2008-23.

10. Zhou MT, Chen CS, Chen BC, Zhang QY, Andersson R. Acute lung injury and ARDS in acute pancreatitis:
Mechanisms and potential intervention. World $\mathbf{J}$ Gastroenterol. 2010;16(17):2094-9.

11. Zhang XP, Wang L, Zhou YF. The pathogenic mechanism of severe acute pancreatitis complicated with renal injury: A review of current knowledge. Dig Dis Sci. 2008;53(2):297-306.

12. Garcia M, Calvo JJ. Cardiocirculatory pathophysiological mechanisms in severe acute pancreatitis. World J Gastrointest Pharmacol Ther. 2010;1(1):9-14.

13. Saluja AK, Steer ML. Pathophysiology of pancreatitis. Role of cytokines and other mediators of inflammation. Digestion. 1999;60(Suppl 1):27-33.

14. Gukovsky I, Gukovskaya AS, Blinman TA, Zaninovic $\mathrm{V}$, Pandol SJ. Early NF- $\mathrm{BB}$ activation is associated with hormone-induced pancreatitis. Am J Physiol. 1998;275(6):G1402-14.

15. Chen X, Ji B, Han B, Ernst SA, Simeone D, Logsdon $\mathrm{CD}$. NF- $\kappa \mathrm{B}$ activation in the pancreas induces pancreatic and systemic inflammatory response. Gastroenterology. 2002;122(2): 448-57.

16. Rakonczay Z Jr, Hegyi P, Takács T, McCarroll J, Saluja AK. The role of NF- $\kappa \mathrm{B}$ activation in the pathogenesis of acute pancreatitis. Gut. 2008;57(2):259-67.

17. Hyun JJ, Lee HS. Experimental models of pancreatitis. Clin Endosc. 2014;47(3):212-6.

18. Lampel M, Kern HF. Acute interstitial pancreatitis in the rat induced by excessive doses of a pancreatic secretagogue. Virchows Arch A Pathol Anat Histol. 1977;373(2):97-117.

19. Saluja A, Saito I, Saluja M, Houlihan MJ, Powers RE, Meldolesi J, et al. In vivo rat pancreatic acinar cell function during supramaximal stimulation with caerulein. Am J Physiol. 1985;249(6 Pt 1):G702-10.

20. Zhao G, Vaszar LT, Qiu D, Shi L, Kao PN. Antiinflammatory effects of triptolide in human bronchial epithelial cells. Am J Physiol Lung Cell Mol Physiol. 2000;11;279(5):L958-66.

21. Gray KD, Simovic MO, Chapman WC, Blackwell TS, Christman JW, Washington MK, et al. Systemic nfkappaB activation in a transgenic mouse model of acute pancreatitis. J Surg Res. 2003;110(1):310-4. 